\title{
The possibilities of company mobility management in Finland
}

\author{
E. Sala ${ }^{1} \&$ N. Karasmaa ${ }^{2}$ \\ ${ }^{1}$ Sito Oy Finnish Consulting Engineers, Finland \\ ${ }^{2}$ Helsinki University of Technology, Transportation Engineering, Finland
}

\begin{abstract}
Company mobility management is still a very new idea in Finland and the concept itself is rather unknown. This is why mobility management has been little used. This research aims to define the responsibility issues of company mobility management in Finland. The most efficient actions to influence employees' mobility behaviour and to encourage employers to include company mobility management as part of the company's values were also considered.

Keywords: company mobility management, mobility plan, sustainable traffic, public transport, daily working trips.
\end{abstract}

\section{Introduction}

The idea of company mobility management is that the company employers could have positive means to influence their employees' travelling habits so that they prefer sustainable models of transport, such as public transport, cycling or walking, to using a private car in daily working travelling $[1,2]$.

Traffic and its disadvantages caused by private cars are the main part of many office based companies' environmental load [3]. For this reason, employers may have a significant role in reducing traffic and its disadvantages. Work places have a good opportunity to have positive influence on the way employees' travel to and from work and on their travelling habits during the day [4]. However, employees have the right to make their own decisions.

The main principle of company mobility management is that employers offer different kinds of means and lures, so that employees would get more alternative choices when travelling to work and that way employees would change their travelling habits and thus prefer more sustainable transport systems. Company 
mobility management tools are so called soft measures, gentle actions, which do not aim to prevent or limit anyone. One example of steering methods is to encourage employees to use public transport with a discounted fare. It is possible to achieve changes immediately with help of active information. However, effective company management needs hard measures in addition to soft measures.

Traditional traffic management is based on constructing new infrastructure, while mobility management tries to influence demands of traffic and habits of travelling. Mobility management is the first step of the four stair model of management based traffic politics (Figure 1).



Figure 1: The four stair model of management based traffic politics.

The mobility management has its historical roots in the United States where the concept in known as Travel Demand Management. In the middle of 1970s the rising concern about consumption of energy, environmental matters and the reach for equality led to this invention of new philosophy of traffic planning in the United States. This new way of thinking was called Travel Demand Management (TDM) [1].

In Europe, the EPOMM (European Platform on Mobility Management) works as an international forum for all organisations interested in mobility management. The EPOMM is a network where mobility management experts share knowledge and ideas, exchange experiences, analyze common problems and look for innovative solutions. The EPOMM is a non-political organisation, which has national or regional governments as a member and it is administered by a Board. Currently the Board is composed of representatives from ministries of The Netherlands, France, Switzerland and Sweden. [5].

The European Union has acknowledged the importance of Mobility Management. The Commission has financed and supported many research and development projects in programmes such as SAVE (17 projects on Mobility Management during 1996-2001), LIFE (including "In town without my car" initiative and European Mobility Week), and INTERREG. The $4^{\text {th }}$ Framework programme included the MOMENTUM [6] and MOSAIC [7] projects. The 
STIR programme examines new urban transport modalities. Mobility management is also part of the "Sustainable Surface Transport" theme of the European Commission's $6^{\text {th }}$ Framework Programme (2002-2006) [8].

Holland is a pioneer of mobility management in Europe. The actions of mobility management mainly concentrate on company mobility management and the actions focus on decreasing the use of private cars on work-related trips. In Holland the mobility management has become a national matter, which is supported with tax-refunds. For example the companies that start to use the benefits of car sharing will be given a free program to co-ordinate carpools [1].

Besides Holland, Great Britain and Belgium are particularly focused on their mobility management actions on daily working trips. In Great Britain and Holland, the actions of mobility management have in particular focused on producing (green) mobility plans, which are made by companies. The mobility plan is a guiding description of how the mobility management is being performed in the company concerned [9].

Sweden is a pioneer of the mobility management in the Nordic Countries. While traffic jams have been the driving force of mobility management in central European countries, the mobility management in Sweden aims to achieve better safety on roads and to decrease the environmental problems. In Sweden the programs and actions of mobility management usually concern the whole city area, city, or district of the city. The secret of Swedish activity in mobility management is the active role of municipalities and cities [1].

\section{Present stage of company mobility management in Finland}

In Finland, the amount of car traffic increases every year. The share of working trips and business-related travelling during the day in the daily traffic system is considerable. Approximately one third of all the trips are caused by journeys to and from work, study or business related trips during the work days. The only group larger than the business-related trips are leisure trips. In the past years the relative share of business travelling of all the trips and traffic output has increased. In Finland the share of business-related travelling of all traffic output is approximately $27 \%$, the average length of trip to work is $13,4 \mathrm{~km}$ and the average length of a business-related trip is $32,3 \mathrm{~km}$. [10].

The company mobility management is still a very new idea in Finland and even the concept itself is rather unknown. This is one of the reasons why mobility management has been hardly used and concrete results of company mobility management's impacts are few. In other countries corresponding analysis have been made, but the results are not directly comparable. For example, the weather conditions and the travelling habits in Finland are different compared with those of Central Europe.

During the past few years much attention has been paid to employers' possibilities to influence their employees' mobility behaviour. For example, in the beginning of the year 2005 the city of Helsinki started a pilot project with a goal of designing a new "as car-free-region as possible" near the heart of Helsinki City. Company mobility management plans have been made only to a 
few companies in connection with some pilot targets. In Finland there is no law or obligations to make company mobility management plans.

\section{Participants and their roles}

The company mobility management has influence on three participants: society, employers and employees (Figure 2). Promoting sustainable transport systems is profitable to them all. This section tries to clarify the roles of these three participants and explain how they profit from company mobility management.

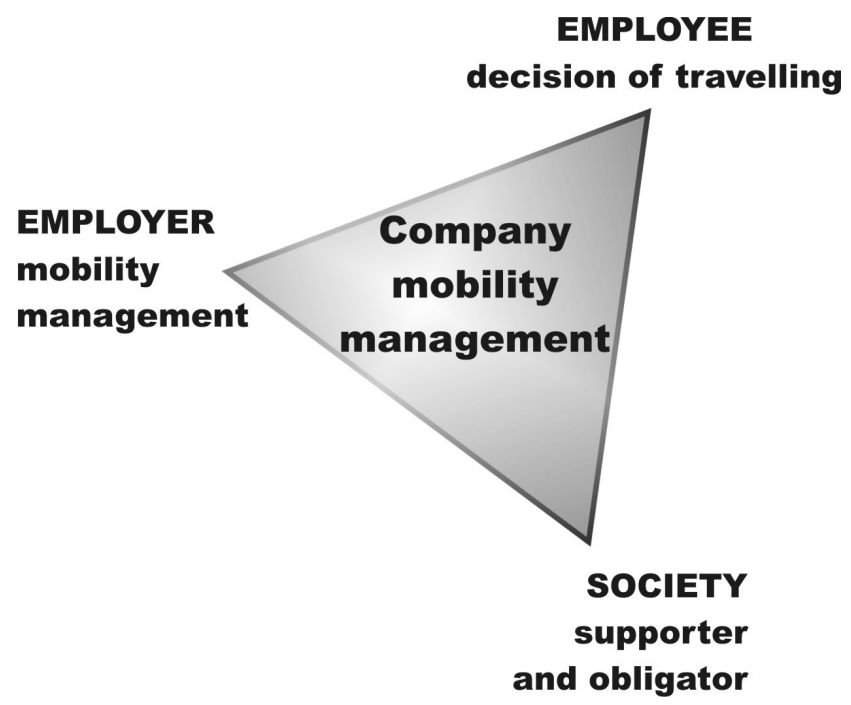

Figure 2: Participants of the company mobility management and their roles.

The society's main role is to support and enforce company mobility management. The main aim from the society's point of view is to increase the use of sustainable transport systems, to make the principles of the company mobility management widely known and accepted and to activate the employers. The society also has to put into action the mobility management in its own organisation. Legislation, rating, architectural instructions and the co-operation between all the sectors of the society are some of the means how to reach the goals.

Society profits from the company mobility management in many ways. For example, travelling becomes more efficient from the energy point of view, disadvantages caused by a high volume of traffic decrease, or at least don't increase, and the national health improves. The process of company mobility management will of course demand financial support from society. But in the long run, when the benefits start to appear, the company mobility management will be economical. 
The employers have the main role in realizing the actions of company mobility management. Their target is to influence the work places' culture of green travelling by promoting sustainable transportation. Employers have to take responsibility for travelling and its influence. To reach their goals, employers can make company mobility management plans voluntary and inform employees about sustainable transportation possibilities. However we must remember that actions always depend on work place itself, so they can not be copied from others.

Employers benefit from actions of company mobility management through employees increased productivity. Employers' action influences on employees so that the atmosphere becomes better, employees become more satisfied and therefore more productive. Expenses can be large, but in some cases they can be very marginal. However, given time, and when profits start to show, the proposal costs will be covered.

When both society and employers have done their share of company mobility management, the employee has the choice of sustainable models of transport, such as public transport, cycling or walking, to revert to a private car in daily working travelling. The goal is that employees would question their present way of travelling to work and choose to use the most sustainable transportation, which is reasonable. In the company mobility management it is the employees' duty to be open-minded and ready to try different ways to travel. It is also desirable that the employee would consider social benefits together with his own.

The employee will benefit a lot from company mobility management: alternative ways of travelling will increase, they may benefit financially, atmosphere at work will get better and their own physical health may improve. However it is very important to remember that despite of the company mobility management, employees will always have the right to make their own decisions about the way they travel to work.

Before it is possible to involve employers in company mobility management, societal authorities and municipalities should approve and start to promote common mobility management on local levels. In this research, three experts on mobility management were asked to define responsibility issues of company mobility management. The research revealed that when promoting mobility management at an early stage it is most important to first create societal steering lines and strategy.

\section{Case studies}

In this research the subject of company mobility management was approached by practice in addition to literary research. Finnish Meteorological Institute and Finnish Institute of Marine Research, both functioning under Ministry of Transport and Communications Finland, were chosen to target organisations of the study. Both institutes moved to new, shared business premises after this research, in September 2005. Although both institutes have several business premises in different parts of Finland, this research concerned only those estates that were moving in September 2005. 
The research of the target organizations was based on the literary research, an inquiry made to the employees (308 answers) and their theme interviews that completed the inquiry (22). The present estates as well as the future shared business premises were evaluated from the work trip point of view. The employers' present stage of travelling to work was studied, analysed and future expectations on steering evaluated.

When an office is moving to another location every employee has to reconsider and question their way of travelling to work. With help of this research mobility management plans were made for both institutes. In this case the employees of Finnish Meteorological Institute and the Finnish Institute of Marine Research were informed of different sustainable transport systems and thus the employers tried to influence their employees travelling habits.

The research was made so that it can be renewed when a suitable time has passed from the institute's change of premises. That way it is possible to examine how it has affected the employees' ways of travelling to and from work. This paper only shows the hypothetical influences.

\subsection{Business premises}

Before the change, the business premises of Finnish Meteorological Institute were located in the central area of Helsinki in Kaisaniemi and Herttoniemi. Almost 450 employees were working in these estates. The estates in Kaisaniemi was located only some hundred meters from the Helsinki Central Railway Station, so the public transportation connections were excellent. The amount of parking space was limited and so this also limited use of cars on trips to work. The business premises in Herttoniemi was situated near the subway stop, but still the employees had to use a bus to get to and from the subway. In Herttoniemi there were more employees coming to work by private car than in Kaisaniemi.

The Finnish Institute of Marine Research consisted of approximately 115 employees. The main premises were situated in Itäkeskus, near the subway stop and the bus station. Public transportation connections were excellent to and from this location.

Both institutes moved to a new shared business premises in Kumpula after the research, in September 2005. There are also quite good public transportation connections in Kumpula, but the biggest drawback is a lack of direct connections to the railway station or subway stop. Public transportation connections are good on weekdays, but on weekends the connections are infrequent. There are some employees working in shifts in both institutes who found late hour connections worse compared with the situation before the move.

\subsection{Results}

The research showed that the institutes change of premises influences on employees' mobility behaviour, mostly by the chance of the working trips lengths and and by the change of public transport services. The average length of employees' trips to work will shorten a little when measured in kilometers, but when measured in minutes the average will increase. The share of 0-3 kilometer 
trips to work will decrease, but the share of 3,1-7 kilometer trips will increase. This means that the possibilities of walking will lessen and possibilities of cycling will grow. The same observation can be seen when examining the results of travelling customs (Figure 3).
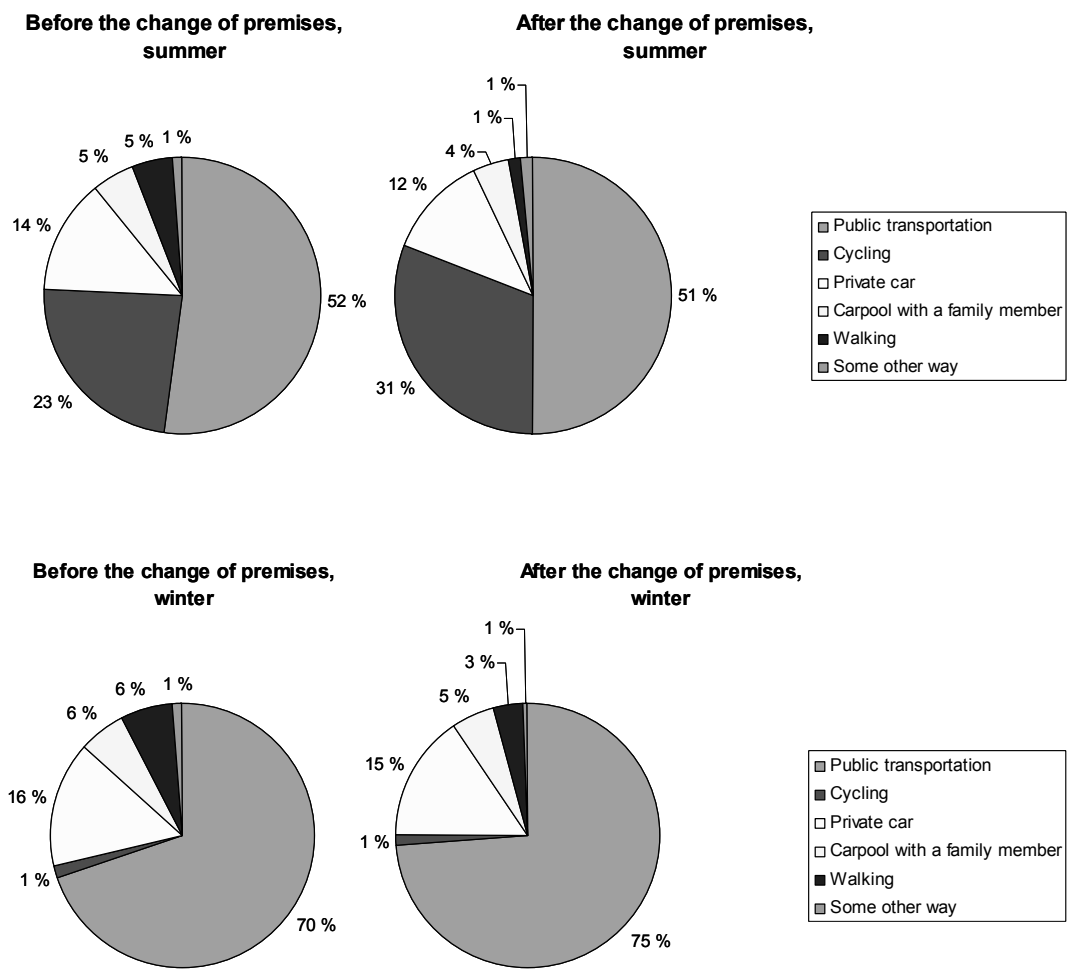

Figure 3: The share of different travelling customs before and after the move in summer and in winter.

Main group of those employees who used public transportation before, will also use it after the move. According to the research the move of the business premises won't remarkably increase the share of people driving by car to work.

When drawing conclusions we must remember that this paper only shows hypothetical influences and the numbers shown in the situations after the move are only expected values. The real results can not be observed until some time has passed and the travelling habits have been adopted.

The research shows that most employees (66\%) accept company mobility management as a part of their work place strategy. Figure 4 shows how different means were approved. 
The research revealed that public transport tickets with discounted fare and improvement of facilities on work places proved to be the most popular steering methods. During the interviews it was also found that employees supported bicycles schemes offered by the employer. Also different kinds of theme days for mobility management were widely supported. Some employees pointed out that it is very important that the employer should try to improve the environment and the public transportation services near the office. Employers should also provide an example to the employees by using sustainable transport systems.

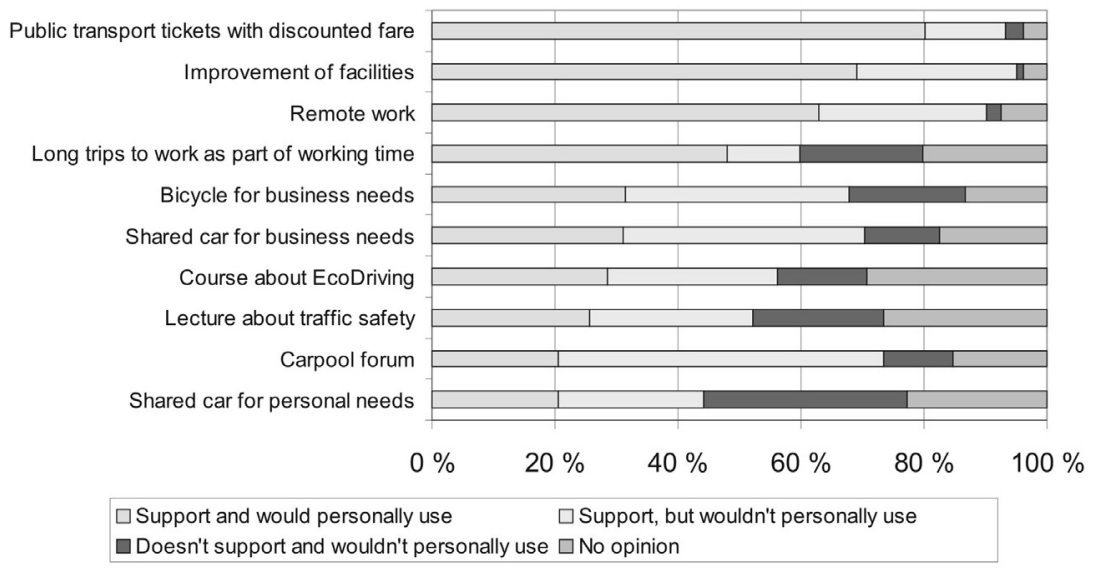

Figure 4: $\quad$ Support of different means of company mobility management.

\section{Conclusions}

It is undoubtedly clear that the employer can influence how employees travel to work. According to this research employees also accept company mobility management as a part of their work place strategy. Nevertheless, employees wish that the management is supportive, not limiting. The research revealed that public transport tickets with discounted fares and improvement of the facilities on work places proved to be the most popular steering methods.

The whole concept of company mobility management will work best when all the different schemes integrate and try to reach the same goals [6]. A lack of concrete and quickly perceptible effects is possibly the main reason why mobility management hasn't yet become popular in Finland. Also the results have received little press in the media.

Company mobility management is still very a new idea in Finland and the concept itself is rather known. Because of this, mobility management has been very little used. It is very important to make the mobility management concept better known in Finland and with help of pilot programs to show its effects. When promoting company mobility management it is the most important aim to get companies to take responsibility of traffic and the disadvantages that it has caused. Employers should be obligated to pay attention to their employees travelling to work and traveling during the day. Despite of all the management, 
employees have the right to make their own decisions about travelling to work. The society's main role is to be supporter and obligator of the company mobility management. During this research it has been possible to realise that authorities, employers and employees are positive about the company mobility management, providing that common rules are defined about means and principles. There is a common will to promote company mobility management. Now we need actions in addition to words.

\section{Acknowledgements}

The report was made in 2005 by the Helsinki University of Technology and it was assigned by Ministry of Transport and Communications and Finnish Road Enterprise.

\section{References}

[1] Kiiskilä K., Koskinen L., Vähä-Rahka M. (2002). Mobility Management and its application to Tampere region. Publications of the Tampere University of Technology, Transportation Engineering 46, Tampere. $103+2$ pages.

[2] Ministry of Transport and Communications (2001). Research promoting walking and cycling should continue as part of the Ministry's and cooperation partners' annual R\&D programmes. Publications of the Ministry of Transport and Communications 6/2001, Helsinki. 60 pages.

[3] City of Helsinki 2005. Project of company mobility management in Helsinki (LIIKKIS). "Luovasti työmatkalle - työmatkaliikkumisen mahdollisuudet" -conference 21.4.2005 ja "Luovasti työmatkalle liikkumisen ohjauksen ideat suunnitelmaksi ja käytäntöön" -conference 20.6.2005. City of Helsinki, environment centre ja Helsingin Energia, Helsinki.

[4] Vähärahka, M., Virrankoski (2002). Company Mobility Management New Mobility Culture on the Daily Working Trips. Publications of the Ministry of Transport and Communications 22/2002, Helsinki. 66 pages.

[5] EPOMM. 2006. European Platform on Mobility Management. http://www.epomm.org

[6] MOMENTUM (1999). Final summary report. Mobility Management for the Urban Environment. NEA. 13 s.

[7] MOSAIC. 1999. Report. NEA, EU 4.F.P, DG TREN, Brussels

[8] Atterbrand, A., Jorde, B., Kasin, O., Krag, T., Silfverberg, B., Skur, J, Stenvall M. (2005). Mobility Management in the Nordic Countries. TemaNord 2005: 539.

[9] Lundgren, K. (2001). Företagets påverkan på arbetspendlingen. Ett internationellt perspektiv på styrmedel för de anställdas resbeteende. Rapport. 2001-02-16. J\&W Management.

[10] The Ministry of Transport and Communications, Finnish Road Administration and the Finnish Rail Administration. (2006). The national passenger transport survey $2004-2005$. Helsinki. 86 pages. 